\title{
A METABOLIC MODEL FOR THE OCEAN QUAHOG ARCTICA ISLANDICA-EFFECTS OF ANIMAL MASS AND AGE, TEMPERATURE, SALINITY, AND GEOGRAPHY ON RESPIRATION RATE
}

\author{
S. BEGUM, ${ }^{1}$ L. BASOVA, ${ }^{2}$ J. STRAHL, ${ }^{1}$ A. SUKHOTIN, ${ }^{2}$ O. HEILMAYER,${ }^{1,4}$ E. PHILIPP, ${ }^{3}$ \\ T. BREY ${ }^{1}$ AND D. ABELE ${ }^{1 *}$ \\ ${ }^{1}$ Alfred-Wegener Institute for Polar and Marine Research (AWI), Bremerhaven, Germany; ${ }^{2}$ Zoological \\ Institute, St. Petersburg, Russia; ${ }^{3}$ Institute of Clinical Molecular Biology, University of Kiel, Germany; \\ ${ }^{4}$ IB Internationales Büro des BMBF beim DLR e. V., Bonn, Germany
}

\begin{abstract}
Owing to its extraordinary lifespan and wide geographical distribution along the continental margins of the North Atlantic Ocean, the ocean quahog Arctica islandica may become an important indicator species in environmental change research. To test for applicability and "calibrate" the Arctica-indicator, metabolic properties of $A$. islandica specimens were compared across different climatic and oceanographic regions. Fully saline populations from Iceland to the North Sea as well as animals from polyhaline and low salinity, environments, the White Sea and the Baltic were included in the study. This calibration centrally includes recordings of growth-age relationships in different populations. Shells were used as age recorders by counting annual growth bands. As a result of this study, we propose a general respiration model that links individual metabolic rates of $A$. islandica from five populations: Norwegian coast, Kattegat, Kiel Bay (Baltic Sea), White Sea and German Bight (North Sea), to body mass, water temperature and site. Temperature exerts distinct site specific effects on respiration rate, which is indicated by $\mathrm{Q}_{10}$ values ranging from 4.48 for German Bight to 1.15 for Kiel Bay animals. Individual age, occurrence of apneal respiratory gaps, parasite infestation and salinity do not affect respiration rate. Respiration of Arctica islandica is significantly below the average of 59 bivalve species when compared at the same temperature and animal mass. This respiration model principally enables the coupling of $A$. islandica life history and population dynamics to regional oceanographic temperature models.
\end{abstract}

KEY WORDS: age, Arctica islandica, mass, respiration, site, temperature

\section{INTRODUCTION}

The ocean quahog Arctica islandica inhabits the continental shelves and slopes at depths between 4-482 $\mathrm{m}$ on both sides of the North Atlantic Ocean along a latitudinal range to the north from Cape Hatteras $\left(\sim 35^{\circ} \mathrm{N}\right)$, on the western Atlantic coast and from the Wadden Sea near Texel $\left(\sim 54^{\circ} \mathrm{N}\right)$, to the Barents Sea $\left(\sim 70^{\circ} \mathrm{N}\right)$ in the east (Nicol 1951, Thompson et al. 1980a, Thompson et al. 1980b, Murawski et al. 1982, Jones 1980, Dahlgren et al. 2000). A. islandica tolerates temperatures between $0^{\circ} \mathrm{C}$ and $16^{\circ} \mathrm{C}$ and has an optimal range between $6^{\circ} \mathrm{C}$ and $10^{\circ} \mathrm{C}$ (Mann 1982). Maximum recorded age of the ocean quahog is close to $400 \mathrm{y}$, and individuals over $100 \mathrm{y}$ are abundant in the North Atlantic (Schöne et al. 2005c, Strahl et al. 2007). Its extreme longevity and wide geographical distribution makes Arctica islandica an attractive model for studies of recent and past climate change (Jones 1980, Thompson et al. 1980a, Murawski et al. 1982, Schöne et al. 2005c) as the shells archive information on environmental conditions that individual animals experience over lifetime (Schöne 2003, Schöne et al. 2004; Witbaard et al. 2003; Epplé et al. 2006, Schöne et al. 2005c).

To read and interpret the Arctica shell archive, we need a sound knowledge of the interacting effects of extrinsic (environmental) and intrinsic (physiological and genetic) factors, which may modify the ageing process in this bivalve species (Abele et al. 2008). The mass specific standard respiration rate (MSR) is a measure of the intensity of basal aerobic metabolism and is primarily controlled by the habitat temperature in ectotherms. MSR has been related to the rate of physiological aging, because higher lifetime oxygen consumption per unit

*Corresponding author. E-mail: Doris.Abele@awi.de tissue mass accelerates senescent processes in cells and tissues (Pearl 1928, Harman 1956, Sohal 1986, Philipp et al. 2005a). This, in turn, means that cold adapted molluscs of any given species can be expected to have longer lifespan than their congeners from warmer waters, as documented for the pearl shell clam Margaritifera margaritifera (Ziuganov et al. 2000).

Arctica islandica are known to modulate their metabolism by performing metabolic shut downs at irregular intervals in which metabolism is rapidly reduced to as low as $10 \%$ of the standard metabolic rates. These metabolically depressed states referred to as metabolic rate depression (MRD), in which the animals burrow a couple of centimeters into the sediment, last between 1 and 7 days (Taylor 1976, Thompson 1984) and may represent a life prolonging mechanism in A. islandica, (Abele 2002, Strahl et al. 2007). In addition, active non-burrowing animals exhibit respiratory breaks. Another behavioral characteristic of Arctica are shorter lasting apneal phases (APs), which do not necessarily involve reduction of metabolic rate (MRD). These transient respiration breaks (i.e., ventilation stops) which last for no more than a couple of minutes, have already been described for other bivalve species (Morley et al. 2007).

Measurements of oxygen consumption rates (e.g., MSR) over age allow to model individual lifetime energy expenditure and serve the approximation of population specific energy budgets (Brey 2001). MSR correlates with mass and age in bivalve molluscs and normally decreases in larger specimens (e.g., Robertson 1979, Ikeda 1985, Hawkins \& Bayne 1992, Heilmayer \& Brey 2003, Heilmayer et al. 2004, Clarke \& Fraser 2004).

Here, we determined MSR of $A$. islandica from five populations (Kattegat, Baltic Sea, North Sea, Norwegian Coast, and White Sea) at mean site specific habitat temperature (HT) and moreover upon acclimation to $5^{\circ} \mathrm{C}$ above $\mathrm{HT}$. 
Experimental warming within the natural temperature window allows to study the effect of temperature on respiration rate in a population and to compare the response to warming between populations of distinct climatic background. Further, we analyzed the frequency and duration of the apneal respiratory pauses (AP) and their dependence on environmental factors (temperature, salinity) and on individual age and size. Based on these measurements, we developed a model of Arctica islandica respiration from the North Atlantic populations, which allows to answer the following questions

(i) How do environmental impact factors like salinity, food, and parasites influence respiration of $A$. islandica?

(ii) How does temperature influence respiration of $A$. islandica with different climatic background?

(iii) How is respiration related with mass and age in each population?

(iv) Do AP phases affect lifetime respiration in different populations?

\section{MATERIAL AND METHODS}

\section{Sampling Sites and Maintenance}

In 2006 Arctica islandica were collected from five different geographic locations (Fig. 1) covering a temperature and salinity gradient of $4-10^{\circ} \mathrm{C}$ and $25-34$, respectively (Table 1 ). Animals were transported alive to the Alfred-Wegener Institute (AWI, Germany) and were kept for 4-6 wk at mean annual habitat temperature of the respective sampling site (Table 1) prior experimentation. Animals were maintained in $60 \mathrm{~L}$ flowthrough aquaria containing $8 \mathrm{~cm}$ of sediment layer and natural seawater of site-specific salinity. The bivalves were fed once a week with DT-live marine plankton (DT, USA, $1 \mathrm{~mL} / \mathrm{animal} /$ week).

\section{Experimental Setup}

Animals of each population were randomly assigned to two different groups. The first subsample was maintained at sitespecific mean annual habitat temperature (HT), whereas the second subsample was acclimated stepwise $\left(1^{\circ} \mathrm{C}\right.$ temperature increase every 2 days) to $5^{\circ} \mathrm{C}$ above mean habitat temperature

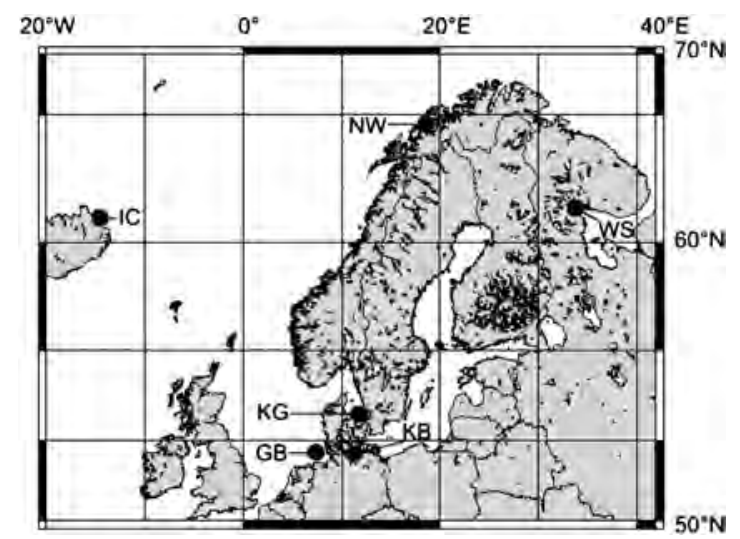

Figure 1. Sampling locations of $A$. islandica, NW: Norwegian Coast, KG: Kattegat, GB: German Bight, WS: White Sea and KB: Kiel Bight. Map generated by online map creator at www.aquarius.ifm-geomar.de.
(ET: elevated temperature) (see Table 1). ET bivalves were kept for at least four weeks at the elevated temperature prior to respiration measurements.

\section{Measurement of Respiration}

Respiration was measured in a multichannel modified intermittent flow system as described by Heilmayer and Brey (2003). Prior to measurements, A. islandica were maintained without food for three days, to eliminate the impact of specific dynamic action (SDA) on respiration (Bayne et al. 1976). Bivalves were allowed to accommodate to the respiration chambers overnight, and oxygen consumption was recorded only in actively respiring animals that had their siphons open to the surrounding water. Respiration chambers were Perspex cylinders that allowed adjusting chamber volume between 100 $600 \mathrm{~mL}$ to animal size (Heilmayer \& Brey 2003). Experimental temperature was maintained stable $\left( \pm 0.5^{\circ} \mathrm{C}\right)$ by placing the chambers in a water bath within a water-jacketed container, thermostatted using a thermo circulator (Julabo FP 40). Three respiration chambers, each with one animal and a control chamber without animal were used for simultaneous measurement in each experiment. After each measurement, the animal was carefully removed from the chamber and oxygen consumption recorded for another $3 \mathrm{~h}$ to determine the microbial oxygen demand in the respective chamber. Oxygen content in the chambers was monitored continuously with oxygen microoptodes connected to a MICROX TX3 array (PreSens, Neuweiler, Germany). Optodes were calibrated to $100 \%$ oxygen solubility in air-saturated and to $0 \%$ in $\mathrm{N}_{2}$-saturated seawater (technical gas with $99.996 \%$ N) at each experimental temperature. Immediately after the measurements, animals were dissected, and examined for the presence of the parasitic Nemertean worm, Malacobdella grossa. Soft tissue was dried at $68^{\circ} \mathrm{C}$ for at least $48 \mathrm{~h}$ to obtain dry mass (DM). Dried tissues were combusted $24 \mathrm{~h}$ at $500^{\circ} \mathrm{C}$ to calculate ash free dry mass (AFDM $=\mathrm{DM}-$ ash). Individual age was inferred from shell growth bands (see below).

\section{Calculation of Metabolic Rates}

Oxygen consumption rates $\left(\mathrm{VO}_{2}, \mu \mathrm{mol} \mathrm{O}_{2} \mathrm{~h}^{-1}\right.$ ind $\left.^{-1}\right)$ were determined from the slope of the oxygen saturation curve after subtraction of the microbial oxygen demand. Percent $\mathrm{O}_{2}$ saturation was transformed to $\mathrm{O}_{2}$ volume concentration using known values of oxygen solubility (Benson \& Krause 1984).

$$
\mathrm{VO}_{2}=\frac{\text { sat } t_{0}}{\text { sat } t_{60}} \cdot \alpha_{O_{2}} \cdot \mathrm{V}_{\text {Chamber }}
$$

$\mathrm{VO}_{2}$ : volume of oxygen consumed $\left(\mu \mathrm{mol} \mathrm{O} \mathrm{O}^{-1}\right.$ ind $\left.^{-1}\right), \alpha_{O_{2}}$ :

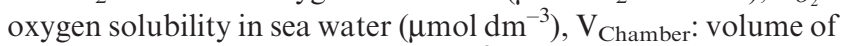
respiration chamber and tubing $\left(\mathrm{dm}^{3}\right)$, sat $t_{0}$ : oxygen saturation $(\%)$ at the beginning of the experiment and sat $t_{60}$ : oxygen saturation (\%) after $60 \mathrm{~min}$ of respiration in the closed system. Apneal respiration (AP) events, manifesting as time periods (intervals) with zero oxygen consumption (Fig. 2), were recorded (frequency and duration) and are included in the computation of overall respiration rate.

Individual mass-specific respiration rates (MSR, $\mu \mathrm{mol} \mathrm{O}_{2}$ $\mathrm{h}^{-1} \mathrm{gAFDM}^{-1}$ ) were calculated according to: 
TABLE 1.

Location, experimental temperature (Depth: sampling depth, HT: mean annual habitat temperature; ET: elevated temperature) and sample size for each population.

\begin{tabular}{|c|c|c|c|c|c|c|c|}
\hline \multirow[b]{2}{*}{ Population } & \multirow[b]{2}{*}{ Location } & \multirow[b]{2}{*}{ Salinity } & \multirow[b]{2}{*}{ Depth (m) } & \multicolumn{2}{|c|}{ Temperature $\left({ }^{\circ} \mathrm{C}\right)$} & \multicolumn{2}{|c|}{ Sample Size } \\
\hline & & & & HT & ET & HT & ET \\
\hline Norwegian Coast & $\begin{array}{c}69^{\circ} 9^{\prime} \mathrm{N} \\
8^{\circ} 57^{\prime} \mathrm{E}\end{array}$ & 33 & $10-30$ & 4 & 9 & 35 & 23 \\
\hline Kattegat & $\begin{array}{l}56^{\circ} 0^{\prime} \mathrm{N} \\
11^{\circ} 8^{\prime} \mathrm{E}\end{array}$ & 31 & 33 & 8 & 13 & 29 & 16 \\
\hline White Sea & $\begin{array}{l}66^{\circ \prime} \mathrm{N} \\
33^{\circ} 38^{\prime} \mathrm{E}\end{array}$ & 25 & 10 & 4 & 9 & 12 & 12 \\
\hline Kiel Bay & $\begin{array}{l}54^{\circ} 32^{\prime} \mathrm{N} \\
10^{\circ} 42^{\prime} \mathrm{E}\end{array}$ & 25 & 25 & 10 & 15 & 28 & 24 \\
\hline German Bight & $\begin{array}{c}54^{\circ} 09^{\prime} \mathrm{N} \\
7^{\circ} 47^{\prime} \mathrm{E}\end{array}$ & 31 & 40 & 10 & 15 & 8 & 10 \\
\hline
\end{tabular}

$$
\mathrm{MSR}=\frac{\mathrm{VO}_{2}}{\mathrm{AFDM}}
$$

The temperature coefficient $\mathrm{Q}_{10}$ was calculated from the overall multiple linear model for mass specific respiration rates between two different temperatures $\left(5^{\circ} \mathrm{C}\right.$ and $\left.10^{\circ} \mathrm{C}\right)$, as

$$
\mathrm{Q}_{10}=\left(\frac{\mathrm{MSR}_{2}}{\mathrm{MSR}_{1}}\right)^{\frac{10}{t_{2}-t_{1}}}
$$

where MSR is the mass specific respiration and $t$ is temperature.

\section{Individual Age Determination}

For the age analysis left shell valves were cleaned with warm $\mathrm{NaOCl}(5 \%)$ solution, rinsed with demineralized water and dried at $60^{\circ} \mathrm{C}$ for $12 \mathrm{~h}$. Each valve was embedded in epoxy resin (Wiko liquid metal FLM-S25), sectioned along the axis of strongest shell growth and dried overnight. Big valves $(\geq 50$ $\mathrm{mm})$ were cut with a table diamond saw (FK/E PROXXON$28070)$. Smaller valves $(<50 \mathrm{~mm})$ were mounted on a Plexiglas block for easier handling during the preparation process and cut with a Buehler low-speed diamond saw. Cross-sections were

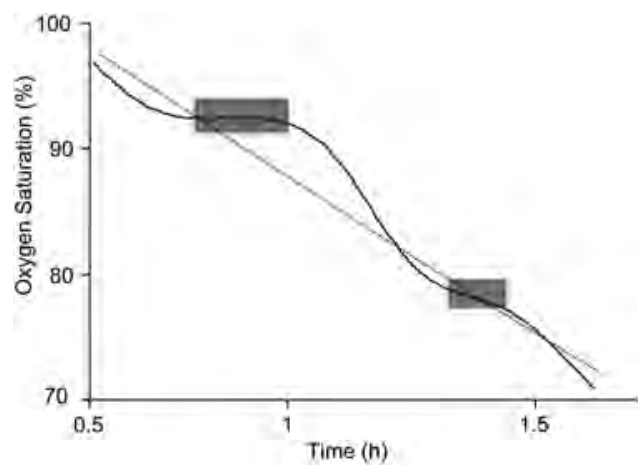

Figure 2. Typical apneal respiration event pattern (AP) during the course of the respiration measurement of one animal (Norwegian coast, $9^{\circ} \mathrm{C}$ ). Grey boxes indicate AP periods characterized by distinctly slower decrease in oxygen saturation. Dotted line shows oxygen decline in a similarly sized individual with no AP. ground on a Buehler low and high speed Grinder and Polisher, using grits of P400, P1200, P2400, and P4000 grade and subsequently polished using a polycrystalline diamond suspension of 1 and $0.1 \mu \mathrm{m}$. The polished shell section was immersed in Mutvei's solution for $20 \mathrm{~min}$ at $37^{\circ} \mathrm{C}$, following the protocol of Schöne et al. (2005b). Immediately afterwards, the etched section was rinsed with demineralized water and allowed to dry on air, resulting in a very clear, three-dimensional growth pattern that reveals distinct annual growth lines. Growth increments were analyzed under a reflected-light stereomicroscope (Olympus SZX12) and digitalized with an Olympus camera (Olympus U-CMD3 Colorview) at $10^{\circ}-90^{\circ}$ angle. Annual growth increments in the outer shell layer were counted following Schöne et al. (2005c) using the image analysis software "analySIS 5.0" (Soft Imaging System $\mathrm{GmbH})$.

\section{Statistical Analysis}

We used analysis of variance (ANOVA) and analysis of covariance (ANCOVA) to explore the relationships between mass-specific respiration rate $\ln (\mathrm{MSR})$, apneal respiration behavior (AP), body mass $\ln (\mathrm{M})$, age, temperature $1 / \mathrm{T}$ (Kelvin), salinity and site (geographical area of collection).

Owing to the strong correlation between body mass and age, these two parameters could not be analyzed simultaneously. We tested for the effects of age on MSR in two different ways: by correlating the residuals of the final multiple linear model with age, and by testing for age effects in a data subset that covered a small body mass range but a wide age range. Effects of temperature, salinity, body mass and age on frequency and duration of apneal phases were analyzed by full interaction ANCOVA. Mahalanobis distances (Barnett \& Lewis 1994) were used to identify multivariate outliers that were excluded from further analysis. All analyses were carried out using the statistical package JMP by SAS Inc (1988).

\section{RESULTS}

Table 2 summarizes the basic information on the 197 quahogs from the five populations we sampled. The number of data available for statistical analysis reduced to 193 after Mahalanobis analysis identified 4 outliers. The German Bight 
TABLE 2.

Total number of measured $A$. islandica in the respiration experiments. $M$. grossa: frequency of occurrence of infestation with Nemertean Malacobdella grossa. AP: frequency of occurrence of apneal respiration events (periods of reduced respiration). nd: not determined.

\begin{tabular}{|c|c|c|c|c|c|c|}
\hline Site & Exp. Temp $\left({ }^{\circ} \mathrm{C}\right)$ & $n$ & Mass Range (g AFDM) & Age Range (yrs) & M. grossa $(\%)$ & AP $(\%)$ \\
\hline \multirow[t]{2}{*}{ Norwegian Coast } & 4 & 35 & $0.35-12.01$ & $6-93$ & 68.57 & 34.29 \\
\hline & 9 & 23 & $0.04-12.01$ & $4-90$ & 56.52 & 30.43 \\
\hline \multirow[t]{2}{*}{ Kattegat } & 8 & 29 & $1.11-2.95$ & $8-71$ & 43.75 & 38.00 \\
\hline & 13 & 16 & $0.91-2.95$ & $11-45$ & 41.38 & 37.50 \\
\hline \multirow[t]{2}{*}{ White Sea } & 4 & 12 & $0.03-0.38$ & $3-31$ & 41.67 & 33.33 \\
\hline & 9 & 12 & $0.12-0.42$ & $12-53$ & 50.0 & 41.67 \\
\hline \multirow{2}{*}{ Kiel Bay } & 10 & 28 & $0.06-1.87$ & 4-29 & 10.71 & 28.57 \\
\hline & 15 & 24 & $0.08-1.42$ & nd & 8.33 & 33.33 \\
\hline \multirow[t]{2}{*}{ German Bight } & 10 & 8 & $5.04-7.34$ & $33-98$ & 0.00 & 87.50 \\
\hline & 15 & 10 & $3.71-6.96$ & $38-94$ & 0.00 & 80.00 \\
\hline
\end{tabular}

population was outstanding because of the lack of small/young animals below $3.7 \mathrm{~g}$ and $33 \mathrm{y}$, no detectable nemertean infestation $(n=18)$, and because of the highest (albeit not significantly different) recorded percentage of apneal phases (AP) $(80 \%$, Table 2$)$.

During an AP event the animals stopped or considerably slowed respiration for between 3 and $31 \mathrm{~min}$ and subsequently continued respiration at rates similar to preAP respiration (Fig. 2). This apneal respiration behavior was observed in about one third of all measurements in all five populations. In those animals that showed APs, average frequency and duration was $0.50 \pm 0.88 \mathrm{AP}$ events $/ \mathrm{h}$ and $5.0 \pm 8.0 \mathrm{AP} \mathrm{min} / \mathrm{h}$. Neither temperature nor salinity, body mass, or age affected AP frequency or duration in a significant manner (full interaction ANCOVA).

Neither the salinity regime (euhaline vs. polyhaline) nor nemertean infestation (yes/no) significantly affected mass specific respiration. MSR was significantly affected by body mass (AFDM), temperature, site and the interactions between these parameters, whereas AP behavior, parasite infestation, and salinity showed no effect. The relationship is described best by the full factorial multiple linear model,

$$
\begin{aligned}
\ln (\mathrm{MSR})= & 22.156-0.224 * \ln (M)-5831.651 / T+b_{3, \mathrm{SITE}} \\
& +b_{4, \mathrm{SITE}} * \ln (M)+b_{5, \mathrm{SITE}} / T
\end{aligned}
$$

$\mathrm{N}=193, \mathrm{R}^{2}=0.656, P<0.001 ;\left[\mu \mathrm{mol} \mathrm{O} \mathrm{h}^{-1} \mathrm{~g}^{-1}\right.$ AFDM, gAFDM, Kelvin] where $b_{3, \text { SITE; }} b_{4}$, SITE; and $b_{5, \text { SITE }}$ are SITE specific parameters (see Table 3 for parameter values). When SiTE effects are not considered, the model reduces to

$$
\ln (\mathrm{MSR})=17.592-0.203 * \ln (M)-4452.9171 / T
$$

$\mathrm{N}=193, \mathrm{R}^{2}=0.493, P<0.001 ;\left[\mu \mathrm{mol} \mathrm{O} \mathrm{h}^{-1} \mathrm{~g}^{-1}\right.$ AFDM, $\mathrm{g}$ AFDM, Kelvin]

Negative age effects on MSR (older animals respiring less) were not detected. The residuals of the multiple linear model were not correlated with age $(P=0.11)$. Within the data subset ranging from 6-12 g AFDM and from 41-94 y of age, MSR was independent of body mass ( $P=0.825$, model: $\ln (\mathrm{MSR})$ versus $\ln (\mathrm{M}), 1 / \mathrm{T}$ and Site), allowing for an independent test of the effect of age on respiration. The corresponding model that uses age instead of $\ln (\mathrm{M})$ also indicates no significant effect of age on $\operatorname{MSR}(P=0.158)$.
Figure 3 visualizes the effects of body mass (negative) and temperature (positive) on MSR. The residuals of the full factorial model are distributed randomly (Fig. 4); our model is an accurate descriptor of the relationship between dependent and independent parameters. Based on the model, $\mathrm{Q}_{10}$ values $\left(5^{\circ} \mathrm{C}-15^{\circ} \mathrm{C}\right)$ were 4.48 for German Bight, 2.63 for Norwegian Coast, 2.34 for White Sea, 1.20 for Kattegat and 1.15 for Kiel Bay.

\section{DISCUSSION}

The intention of this study was to build a general predictive model of respiration in $A$. islandica, taking into account significant biotic (body mass, age, parasites, apneal respiration behavior) and abiotic (temperature, salinity, SITE) parameters. The model (Table 3, Fig. 3) is of acceptable accuracy and precision (Fig. 4) and fits external data (as shown later). There are however two basic constraints that should be kept in mind when applying this model. Firstly, the body mass range differs greatly between populations, from small animals $(\leq 0.42 \mathrm{~g}$ AFDM) in the White Sea group to mostly large bivalves ( $\geq 3.71 \mathrm{~g} \mathrm{AFDM}$ ) sampled in German Bight (Table 2). We tried to minimize these differences through the selection of the most similarly sized experimental animals, but had to deal with the material available. This discrepancy may have biased SITE effects to an unknown extent, particularly for SiTE-body mass and the SiTE-temperature interactions. Secondly, besides temperature,

TABLE 3.

Parameter values of the multiple linear prediction model. $\ln (\mathrm{MSR})=22.156-0.224 * \ln (\mathrm{M})-5831.651 / \mathrm{T}+\mathrm{b}_{3, \mathrm{~S}_{\text {ITE }}}+\mathrm{b}_{4, \mathrm{~S}_{\text {ITE }}}$ $* \ln (\mathrm{M})+\mathbf{b}_{5, \text { SтTE }} / \mathrm{T}$; [ $\mu \mathrm{mol} \mathrm{O} \mathbf{O}^{-1} \mathrm{~g}^{-1} ; \mathrm{g}$ AFDM; Kelvin]; $\boldsymbol{n}=\mathbf{1 9 3}$, $\mathbf{R}^{2}=0.656, P<0.001$. Reduced model (SITE effects neglected): $\ln (\mathrm{MSR})=17.592-0.203 * \ln (\mathrm{M})-4452.917 / \mathrm{T} ; n=193$, $\mathrm{R}^{2}=0.493, P<0.001$.

\begin{tabular}{lrrr}
\hline \hline \multicolumn{1}{c}{ Site } & $\mathbf{b}_{\mathbf{3} \text {,StTE }}$ & $\mathbf{b}_{\mathbf{4} \text {,STTE }}$ & \multicolumn{1}{c}{$\mathbf{b}_{\mathbf{5} \text {,StTE }}$} \\
\hline Norwegian Coast & 7.091 & 0.144 & $-1,923.777$ \\
Kattegat & -14.984 & 0.176 & $4,339.745$ \\
White Sea & 2.947 & -0.483 & -967.735 \\
Kiel Bay & -16.272 & -0.026 & $4,732.580$ \\
German Bight & 21.218 & 0.190 & $-6,180.815$ \\
\hline
\end{tabular}




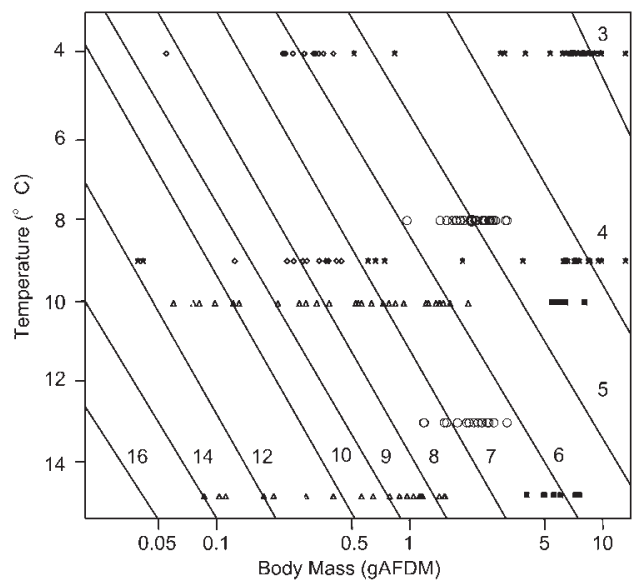

Figure 3. Visualization of the relationship between MSR ( $\mu \mathrm{mol} \mathrm{O}_{2} \mathbf{h}^{-1}$ $\mathrm{g}^{-1}$ AFDM), body mass (gAFDM) and temperature (here shown in ${ }^{\circ} \mathrm{C}$ ) as described by the reduced multiple linear model (SITE effects neglected, Table 3). Lines represent MSR isopleths ranging from 2-14 $\mu \mathrm{mol} \mathrm{O}_{2} \mathrm{~h}^{-1}$ $\mathrm{g}^{-1}$ AFDM. Superimposed are the body mass / temperature data of all MSR measurements. Triangles: Kiel Bay, diamonds: White Sea, squares: German Bight, stars: Norwegian Coast, circles: Kattegat.

salinity, water depth, and geographical location we know little about the five SitEs. Hence, we are not able to explain the causes of the observed Site effects. Possibly, stress (e.g., caused by hydrodynamics or by water sediment load; Jarmillo et al. 2008) or food availability (e.g., different levels of primary production; Sejr et al. 2004) may play a role. Therefore, we recommend to apply the reduced model (SITE effects neglected) to predict MSR of $A$. islandica from other populations and areas. This may reduce accuracy in the absolute values, but will maintain the precision of the predicted trends.

For a first testing, we used this reduced model to compare predicted values of MSR with those measured by Taylor and Brand (1975) in A. islandica collected from Laxey Bay, Isle of Man as well as off the Danish coast. The data set consists in 30 measurements carried out by Taylor and Brand (1975) and 11 additional data points taken from Bayne (1971). Respiration was measured at $10^{\circ} \mathrm{C}$, and the study was aimed at investigating the effect of decreasing $\mathrm{PO}_{2}$ on $A$. islandica, (i.e., measurements

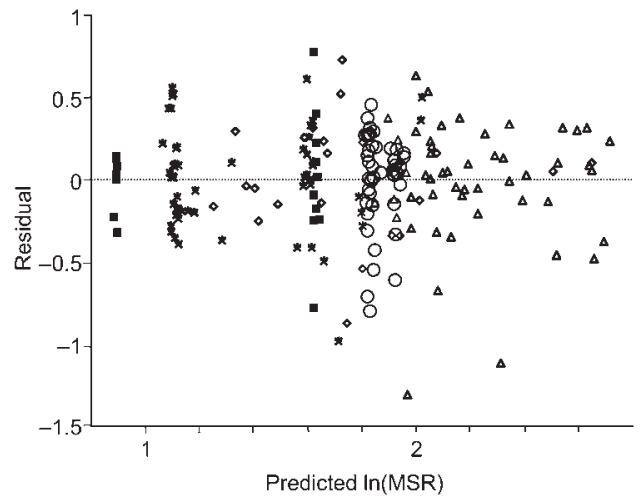

Figure 4. Residual plot (residual versus predicted values) of the full factorial multiple linear model (Table 3). Triangles: Kiel Bay, diamonds: White Sea, squares: German Bight, stars: Norwegian Coast, circles: Kattegat. continued down to $10 \%$ [2-3 $\mathrm{kPa}$ ] of normoxic oxygen saturation $\left[21 \mathrm{kPa}=100 \% \mathrm{PO}_{2}\right]$ ).

Below $5 \mu \mathrm{mol} \mathrm{O}_{2} \mathrm{~h}^{-1} \mathrm{~g}^{-1}$ the MSR-model accuracy was rather good $(<1 \mu \mathrm{mol})$, but decreased constantly with increasing MSR (i.e., measured MSR was increasingly underestimated at higher consumption values) (Fig. 5). A matched pair test confirms this view, measured and predicted MSR do not differ significantly below $20 \mu \mathrm{mol} \mathrm{O} \mathrm{h}^{-1} \mathrm{~g}^{-1}$ of measured MSR $(P=0.968)$, but the difference becomes significant $(P<0.001)$ when the whole range of data is compared. Hence, the small animals $(n=11)$ with high MSR cause a problem (Fig. 5). Interestingly, all of these have been measured by Bayne (1971) so that we cannot exclude a consistent methodical bias. These small animals may have been in poor physiological condition and may have lost their ability to regulate oxygen consumption under hypoxia, as suggested by Taylor and Brand (1975).

Some unexpected findings arose from our measurements, which need to be given some further consideration:

\section{Why is There No Age Effect in A. islandica Metabolism?}

The lack of negative age effects on respiration can be explained in the context of an apparent maintenance of physiological fitness and only minor accumulation of senescence indicators over age (Fluorescent age pigments and protein carbonyl accumulation) in the extremely long lived Icelandic $A$. islandica. In these long-lived animals, the activity of the mitochondrial marker enzyme citrate synthase (CS) remained constant in mature animals from 33 y into old age, with our oldest experimental specimens approaching 200 y (Strahl et al. 2007, Abele et al. 2008). These findings contrast studies of shorter lived bivalves, including data obtained for the blue mussel Mytilus edulis, which reaches maximum age of up to $30 \mathrm{y}$. Sukhotin and coauthors documented decreasing respiration and filtration rates in M. edulis from a subarctic White Sea population above $6 \mathrm{y}$ of animal age, indicating that blue mussels either lose or reduce respiratory capacities (Sukhotin \& Pörtner 2001, Sukhotin et al. 2003) and water pumping activity (Sukhotin et al. 2003) over lifetime. The present evidence suggests that in $A$. islandica MSR is independent of age for at least the first $100 \mathrm{y}$ of lifetime. Most of the animals we

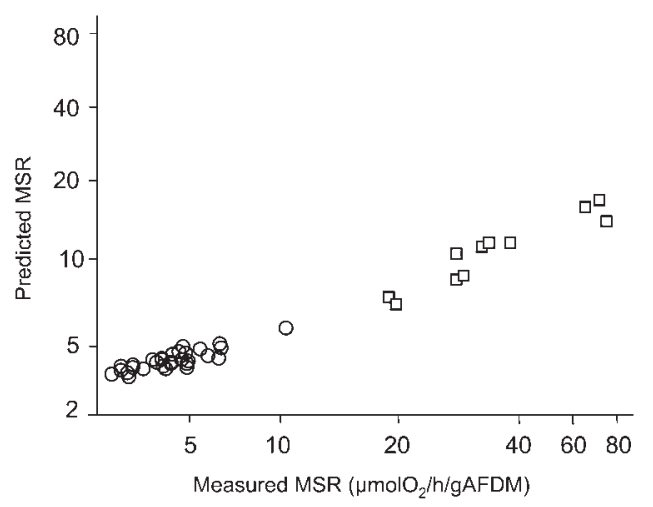

Figure 5. Comparison of reduced model estimates with measurements of A. islandica respiration published by Taylor and Brand (1975). Accuracy is $<1 \mu \mathrm{mol}$ below $20 \mu \mathrm{mol} \mathrm{O}_{2} \mathrm{~h}^{-1} \mathrm{~g}^{-1}$. Circles: measured by Taylor \& Brand; squares: measured by Bayne (1971) (fide Taylor \& Brand 1975). 
have studied here were younger than $100 \mathrm{y}$ and the senescent decline of MSR may yet not have been detectable in our samples. However, as these cohorts seem to represent the most abundant age ranges in all populations they suffice for modeling of the overall metabolic capacities and energy demand in a given population.

Do Different Climatic Adaptations in A. islandica Populations Affect the Respiratory Response to Elevated Temperature?

Temperature is assumed to be the most important environmental modulator of poikilotherm metabolism (Thompson 1984). Accordingly, the respiration model in Figure 3 shows mass specific metabolic activity of $A$. islandica to be significantly higher at higher temperature. Thermal adaptations in bivalves are best described by an Arrhenius model of temperature dependence of metabolic rates (Peck \& Conway 2000, Heilmayer \& Brey 2003), and $\mathrm{Q}_{10}$ is a good summary descriptor of the temperature effect. There is evidence that bivalves become more temperature sensitive with increasing body mass (Bayne et al. 1976) (i.e., $Q_{10}$ may be linked to body mass). Hence, differences in $\mathrm{Q}_{10}$ between Sites may be partially caused by differences in size range between our population samples (see above). To evaluate this question, we reduced the whole data set to a common mass range from $0.3-6$ g AFDM $(n=123)$ for all populations and built a new multiple linear model to predict MSR. The corresponding $\mathrm{Q}_{10}$ values, 4.88 for German Bight, 2.72 for Norway, 2.70 for White Sea, 1.22 for Kattegat and 1.37 for Kiel Bay did not provide a consistent picture: clipping of either very small animals (from Kiel Bay and White Sea population) or of very large animals (from German Bight, Norway population) both increased $\mathrm{Q}_{10}$. Thus, animal body mass differences can obviously not explain the observed differences in site-specific $\mathrm{Q}_{10}$ values. Instead, the strong interactions between SITE and temperature as well as body mass (Table 3) point towards site-specific adaptations in the physiological response to temperature. The exceptionally high value for the German Bight animals should be viewed with caution. A $\mathrm{Q}_{10}$ of 4.88 is quite high, particularly compared with the adjacent Kattegat.

Does AP Affect Respiration and Do We See Site or Temperature Specific Differences in AP Occurrence or Duration?

Respiratory pauses (APs) did not affect long term (over hours) respiration in $A$. islandica (Fig. 2). Moreover, neither the percentage of AP-performing animals, nor the length of the APs differed between populations. We did not analyze the AP pattern of each specimen in detail, but the general picture is that of a nonrhythmic, very variable and individual behavior. Apparently, AP is not caused by external triggers, but reflects an internal behavioral pattern in the bivalves. Apneal behavior or to the contrary short bouts of elevated respiration have already been observed in other cold adapted bivalves, such as the Antarctic mud clams Laternula elliptica (Morley et al. 2007) and the protobranch Yoldia eightsi (Abele et al. 2001). There is a general trend in bivalves to keep mantle water $\mathrm{PO}_{2}$ on low and protective levels, and water breathers like Arctica islandica which live in the sediment water interface, must cope with fluctuant and up to normoxic oxygen levels in the inhaled water. Short bouts of accelerated or reduced respiration may contrib-

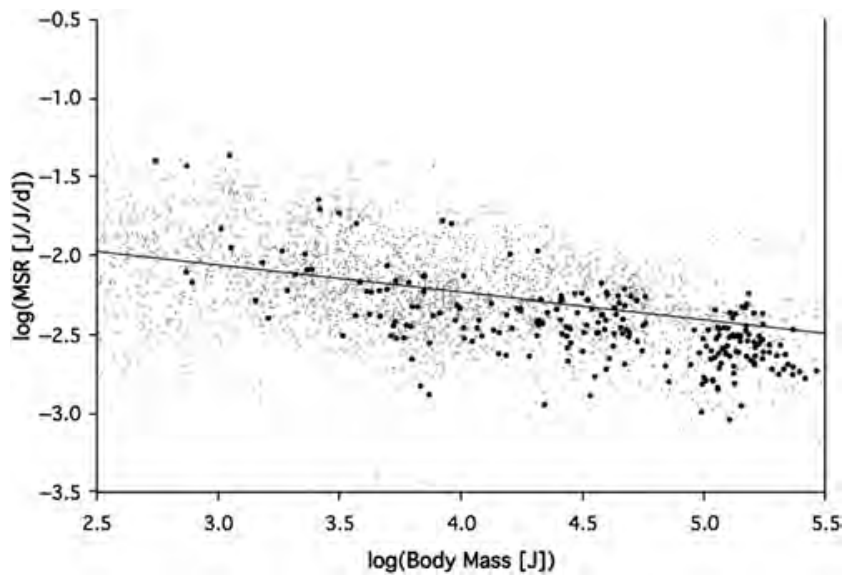

Figure 6. Temperature adjusted $\left(10^{\circ} \mathrm{C}\right)$ mass specific respiration rate (MSR, $\mathrm{J} / \mathrm{J} / \mathrm{d}$ ) versus body mass $\mathrm{M}(\mathrm{J})$ in Arctica islandica (black dots, $n=234$; (Taylor \& Brand 1975) and own measurements) compared with data from 58 bivalve species $(n=3583)$. Straight line indicates regression of $\log (\mathrm{MSR})$ on $\log (\mathrm{M})$ over all data. MSR of $A$. islandica is significantly $(P<0.001)$ below bivalve average MSR. For data, species and references see Brey (2001). To unify units of mass and respiration, original body mass data were converted to Joule and respiration rates to Joule/day $(1 \mu \mathrm{mol}$ $\mathrm{O} 2=46.8 \mathrm{~J}$, Gnaiger 1983, and $1 \mathrm{mg} \mathrm{AFDM}=21.82 \mathrm{~J}$ in bivalves, Brey 2001)

ute to the regulation of shell water $\mathrm{PO}_{2}$. This behavior should not be confused with real metabolic rate depression (MRD), which represents a distinct and deliberate shut down of metabolic activity (Taylor 1976, Thompson 1984, Abele 2002, Strahl et al. 2007)

According to the rate of living-theory of aging (Pearl 1928), the MSR of the long-lived Arctica islandica should range at the lower end of the MSR range of bivalves. We compared 3583 respiration measurements from 58 different bivalve species compiled by Brey (2001), with 234 measurements of A. islandica, including the data of Taylor \& Brand (1975) and our own measurements (Fig. 6). Regression of log (MSR, adjusted to $\left.10^{\circ} \mathrm{C}\right)$ over $\log (\mathrm{M})$ indicates MSR of $A$. islandica to be significantly $(P<0.001)$ lower than the compiled bivalve MSR (Fig. 6). Note that the few isolated black dots showing higher respiration for Arctica islandica are from Bayne (1971), and do not fit the general Arctica model. The overall low respiration in $A$. islandica indicates that the quahog belongs to the low tissue oxygenation-type, presumably keeping tissue $\mathrm{PO}_{2}$ on extremely low levels during most of its burrowed and nonburrowing lifetime.

\section{ACKNOWLEDGMENTS}

The authors thank L. Camus and M. Sejr for kindly providing animals from Norway and the Kattegat region, and Boris Klein for helping with the animal transport from Norway. The study was funded through the excellence initiative of the DAAD-Helmholtz fellowship (Grant no: A0522368) to S. B. and DAAD A056588 and International Bureau-grant RUS-07/ A11 to L. B, as well as by the German Science foundation (DFG) Ab124/10-1. The authors also thank the referees for their efforts in revising and improving the paper. 


\section{LITERATURE CITED}

Abele, D. 2002. Toxic oxygen: the radical life giver. Nature 420:27.

Abele, D., J. Strahl, T. Brey \& E. E. R. Philipp. 2008. Imperceptible senescence: Ageing in the ocean quahog Arctica islandica. Free Radic. Res. 42:474-480.

Abele, D., C. Tesch, P. Wencke \& H. O. Pörtner. 2001. How does oxidative stress relate to thermal tolerance in the Antarctic bivalve Yoldia eightsi? Antarct. Sci. 13:111-118.

Barnett, V. \& T. Lewis. 1994. Outliers in statistical data, 3rd ed. John Wiley and Sons, Chichester, pp. 584.

Bayne, B. L., R. J. Thornpson \& J. Widdows. 1976. Physiology I. In: B. L. Bayne, editor. Marine mussels. Their ecology and physiology. Cambridge: Cambridge University Press. pp. 121-206.

Bayne, B. L., 1971. Oxygen consumption by three species of lamellibranch molluscs in declining ambient oxygen tension. Comp. Biochem. Physiol. 40(a):955-970.

Benson, B. B. \& D. Krause, Jr. 1984. The concentration and isotopic fractionation of oxygen dissolved in freshwater and seawater in equilibrium with the atmosphere. Limnol. Oceanogr. 29:620-632.

Brey, T. 2001. Population dynamics in benthic invertebrates. A virtual handbook. http://www.thomas-brey.de/science/virtualhandbook.

Clarke, A. \& K. P. P. Fraser. 2004. Why does metabolism scale with temperature. Funct. Ecol. 18:243-251.

Dahlgren, T. G., J. R. Weinberg \& K. M. Halanych. 2000. Phylogeography of the ocean quahog (Arctica islandica): influences of paleoclimate on genetic diversity and species range. Mar. Biol. 137:487-495.

Epplé, V. M., T. Brey, R. Witbaard, H. Kuhnert \& J. Pätzold. 2006. Sclerochronological records of Arctica islandica from the inner German Bight. Holocene 16:763-769.

Gnaiger, E. 1883. Calculation of energetic and biochemical equivalents of respiratory oxygen consumption. In: E. Gnaiger \& H. Forstner, editors. Polarographic oxygen sensors. Berlin: Springer. pp. 337-345.

Harman, D. 1956. Aging: a theory based on free radical and radiation biology. J. Gerontol. 11:298-300.

Hawkins, A. J. S. \& B. L. Bayne. 1992. Physiological interrelations and the regulation of production. In: E. Gosling, editor. The mussel Mytilus. Ecology, physiology, genetics, and culture. Developments in aquatic and fisheries science, Vol. 25. Amsterdam: Elsevier. pp. 171-222.

Heilmayer, O., T. Brey, D. Storch, A. Mackensen \& W. E. Arntz. 2004. Population dynamics and metabolism of Aequipecten opercularis (L) from the Western English Channel (Roscoff, France). J. Sea Res. 52:33- 44.

Heilmayer, O. \& T. Brey. 2003. Saving by freezing? Metabolic rates of Adamussium colbecki in a latitudinal context. Mar. Biol. 143:477-484.

Ikeda, T. 1985. Metabolic rate of epipelagic marine zooplankton as a function of body mass and temperature. Mar. Biol. 85:1-11.

Jarmillo, E., J. Lopez, M. Incera, M. Lastra, H. Contreras \& C. Duarte. 2008. Sedimentary characteristics, macroinfauna and types and abundances of bivalves in a tidal flat of the nord-Patagonic archipelagos, Chile. Vie Et Milieu-Life And Environment 58:11-23.

Jones, D. S. 1980. Annual cycle of shell growth increment formation in two continental shelf bivalves and its paleoecologic significance. Paleo. 6:331-340.

Mann, R. 1982. The seasonal cycle of gonadal development in Arctica islandica from the southern new England shelf. Fish. Bull. (Wash. D. C.) $80: 315-326$.

Morley, S. A., L. S. Peck, A. J. Miller \& H. O. Portner. 2007. Hypoxia tolerance associated with activity reduction is a key adaptation for Laternula elliptica seasonal energetics. Oecolologia 153:29-36.

Murawski, S. A., J. W. Ropes \& F. M. Serchuk. 1982. Growth of the ocean quahog, Arctica islandica, in the Middle Atlantic Bight. Fish. Bull. (Wash. DC.) 80:21-34.

Nicol, D. 1951. Recent species of the Veneriod pelecypod Arctica. J. Wash. Acad. Sci. 41:102-106.

Pearl, R. 1928. The rate of living. Alfred Knopf, New York.

Peck, L. S. \& L. Z. Conway. 2000. The myth of metabolic cold adaptation: oxygen consumption in stenothermal Antarctic bivalves
In: E. Harper, J. Taylor \& A. Crame, editors. Evolutionary biology of the Bivalvia. London: Geol. Soc. London Spec. Publ.

Philipp, E., T. Brey, H. O. Pörtner \& D. Abele. 2005a. Chronological and physiological ageing in a polar and a temperate mud clam. Mech. Ageing Dev. 126:589-609.

Robertson, A. L. 1979. The relationship between annual production: biomass ratios and lifespans for marine macrobenthos. Oecologia 38:193-202.

SAS. 1988. SAS/STAT User's Guide release 6.03 Edition. SAS Institute Inc. Cary, NC.p.1028.

Schöne, B. R. 2003. A clam-ring master-chronology constructed from a short-lived bivalve mollusc from the northern Gulf of California, USA. Holocene 13:39-49.

Schöne, B. R., E. Dunca, J. Fiebig \& M. Pfeiffer. 2005b. Mutvei's solution: an ideal agent for resolving microgrowth structures of biogenic carbonates. Palaeogeogr. Palaeoclimatol. Palaeoecol. 228: 149-166.

Schöne, B. R., J. Fiebig, M. Pfeiffer, R. Gles, J. Hickson, A. L. A. Johnson, W. Dreyer \& W. Oschmann. 2005c. Climate records from a bivalve Methuselah (Arctica islandica, Molluska; Iceland). Palaeogeogr. Palaeoclimatol. Palaeoecol. 228:130-148.

Schöne, B. R., A. D. Freyre Castro, J. Fiebig, S. D. Houk, W. Oschmann \& I. Kröncke, 2004. Sea surface water temperatures over the period 1884-1983 reconstructed from oxygen isotope ratios of a bivalve mollusk shell (Arctica islandica, southern North Sea). Palaeogeogr. Palaeoclimatol. Palaeoecol. 212:215232.

Sejr, M. K., J. K. Petersen, J. K. Thomas \& S. Rysgaard. 2004. Effects of food concentration on clearance rate and energy budget of the Arctic bivalve Hiatella arctica (L) at subzero temperature. J. Exp. Mar. Biol. Ecol. 311:171-183.

Sohal, R. S. 1986. The rate of living theory: a contemporary interpretation. In: K. G. Collatz \& R. S. Sohal, editors. Insect aging. Berlin: Springer-Verlag. pp. 23-44.

Strahl, J., E. Philipp, T. Brey, K. Broeg \& D. Abele. 2007. Physiological ageing in the Icelandic population of the ocean quahog Arctica islandica. Aquat. Biol. 1:77-83.

Sukhotin, A. A., D. L. Lajus \& P. A. Lesin. 2003. Influence of age and size on pumping activity and stress resistance in the marine bivalve Mytilus edulis. J. Exp. Mar. Biol. Ecol. 284:129-144.

Sukhotin, A. A. \& H. O. Pörtner. 2001. Age-dependence of metabolism in mussels Mytilus edulis (L.) from the White Sea. J. Exp. Mar. Biol. Ecol. 257:53-72.

Taylor, A. C. 1976. Burrowing behaviour and anaerobiosis in the bivalve Arctica islandica (L.). J. Mar. Biol. Ass. UK. 56:95109.

Taylor, A. C. \& A. R. Brand. 1975a. Effects of hypoxia and body size on the oxygen consumption of the bivalve Arctica islandica (L). J. Exp. Mar. Biol. Ecol. 19:187-196.

Thompson, I., D. S. Jones \& J. W. Ropes. 1980a. Advanced age for sexual maturity in the ocean quahog Arctica islandica (Mollusca: Bivalvia). Mar. Biol. 57:35-39.

Thompson, I., D. S. Jones \& D. Dreibelbis. 1980b. Annual internal growth banding and life history of the ocean quahog, Arctica islandica (Mollusca: Bivalvia). Mar. Biol. 57:25-34.

Thompson, R. J. 1984. The reproductive cycle and physiological ecology of the mussel Mytilus edulis in a subarctic, non-estuarine environment. Mar. Biol. 79:277-288.

Witbaard, R., E. Jansma \& U. Sass Klaassen. 2003. Copepods link quahog growth to climate. J. Sea Res. 50:77-83.

Ziuganov, V., E. S. Miguel, R. J. Neves, A. Longa, C. Fernandez, R. Amaro, V. Beletsky, E. Popkovitch, S. Kaliuzhin \& T. Johnson. 2000. Life span variation of the freshwater pearl shell: a model species for testing longevity mechanisms in animals, AMBIO. $J$. Hum. Environ. 29:102-105. 